\title{
Chenopodium Oil
}

National Cancer Institute

\section{Source}

National Cancer Institute. Chenopodium Oil. NCI Thesaurus. Code C72184.

An oil obtained from Chenopodium ambrosioides plants. Chenopodium oil is considered to be toxic but has been used for its anthelmintic properties. 